\title{
Micro, small, and medium enterprises (MSMEs): The emerging market analysis
}

\author{
Fatimah $^{\mathrm{a}}$, Abid Djazulia ${ }^{*}$ and Fitriya Fauzi ${ }^{\mathrm{a}}$
}

\begin{tabular}{l}
${ }^{a}$ Universitas Muhammadiyah Palemban \\
\hline C H R O N I C L E \\
\hline Article history: \\
Received March 9, 2021 \\
Received in revised format May \\
112021 \\
Accepted May 312021 \\
Available online \\
May 312021 \\
\hline Keywords: \\
Technology Human Resource \\
Business Capabilities \\
Performance \\
MSME
\end{tabular}

\section{Introduction}

Micro, Small, and Medium Enterprises (MSMEs) proliferate in Indonesia, particularly in South Sumatra. MSMEs can increase a nation's income and reduce unemployment rates. Based on the Indonesian Central Statistics Agency (BPS) data in 2015, MSMEs contributed 58.92\% to the Gross Domestic Product (GDP) and absorbed 97.30\% of the country's total workforce. Due to this rationale, the Indonesian government pledged to improve the number of MSMEs in the country. Specifically, it has strategized to create 20 million new MSMEs by 2020. Besides adding more quantity, the Indonesian government should also consider its MSMEs' quality. There are several aspects an MSME must possess in order to be competitive. These include the owner and employees' level of education, skills and entrepreneurship capability, access to business development agencies, access to financing sources, as well as the ease of licensing and transaction fees. Additionally, according to Alyas and Rakib (2017), various internal factors are hindering MSMEs growth. These constitute capital capabilities, weak management systems, the quality and quantity of human resources, less intensive marketing activities, and limited production means. Furthermore, Nicolescu (2009) stated that MSMEs rely on internal and external factors to survive and foster. Internal factors consist of business scale, stakeholders' personality, educational background, and culture (internal training). These can affect the level of productivity and innovation. On the other hand, external factors are access to capital, government policy, and economic conditions of a country. According Utami and Lantu (2014), there are six primary variables shaping MSMEs' competitiveness. They are the availability and conditions of the business environment, policy and infrastructure, research and technology, financial support and partnerships, and performance.

* Corresponding author

E-mail address: fitriya.fauzi@gmail.com (A. Djazuli)

(C) 2021 Growing Science Ltd. All rights reserved. doi: $10.5267 / j . a c .2021 .5 .019$ 
Existing studies primarily focus on either internal or external factors (for example see Nicolescu, 2009; Mutandwa, Taremwa, \& Tubanambazi, 2015). Few of them discussed both factors in one study holistically. Therefore, there is a demand to discuss how external and internal factors together affect MSMEs performance. In addition, in Indonesian context, research discussing factors affecting MSMEs predominantly concentrate on those residing in Java island (see Aribawa, 2016; Hanum \& Sinarasri, 2018; Rahayu, 2017). In terms of MSMEs ecosystem, the region is more developed than others in Indonesia. There is an urgency to use other MSMEs samples located in regions other than Java. This study attempts to investigate both the internal and external factors affecting MSMEs performance in South Sumatra. The use of samples from South Sumatra represents those MSMEs in regions other than Java that is neglected by researchers and policymakers. Theoretically, this study enriches the MSMEs discussion in developing countries. Specifically, the discussion contributes to expanding the factors affecting MSMEs holistically. Practically, this investigation's results can provide an insight into the government of South Sumatra on what to improve to enhance the performance and competitiveness of the MSMEs in the region.

The structure of this paper is as follows. Section 2 reviews the relevant literature. Section 3 analyses the methodology that has been used to conduct empirical research on the factors affecting the Micro, Small, and Medium Enterprises. Sections 4 and 5 provide findings and conclusions subsequently.

\section{Literature Review}

\subsection{Micro, Small, and Medium Enterprises in the Indonesian Context}

Based on Law No. 20 of 2008 regarding Micro, Small, and Medium Enterprises, there are four categories of enterprises in Indonesia. Firstly, micro-enterprises are productive enterprises owned by individuals or business entities and individuals who meet the following criteria: a) has a net worth of Rp. 50,000,000 (fifty million rupiahs) excluding land and buildings; b) has an annual sales turnover of Rp. 300,000,000 (three hundred million rupiahs). Secondly, small business is an economical and productive as well as stand-alone enterprise performed by an individual or business entity that is not a subsidiary or not the branch companies controlled by or be a part either directly or indirectly from medium or large business, with the following criteria: a) has a net worth of between Rp. 50,000,000 (fifty million rupiahs) up to a maximum of Rp. 500,000,000 (five hundred million rupiahs), - excluding land and buildings; $b$ ) has an annual sales turnover of more than Rp. 300,000,000 (three hundred million rupiahs) up to a maximum of Rp. 2,500,000,000 (two billion five hundred million rupiahs). Thirdly, medium-sized businesses are productive economic activities that stand-alone carried by an individual or business entity not subsidiaries or branches of companies owned, controlled or become part either directly or indirectly with a small business or a large business, with the following criteria: a) has a net worth of more than Rp. 500,000,000 (five hundred million rupiahs) to Rp. 10,000,000,000 (ten billion rupiahs) not including land and buildings; b) has an annual sales turnover of more than Rp. 2,500,000,000 (two billion five hundred million rupiahs) up to the maximum of Rp. $50,000,000,000$ (fifty billion rupiah). In the context of South Sumatra, Table 1 shows the distribution of MSMEs in the region. Although the quantity is substantial, a complete and comprehensive analysis of the MSMEs' quality and competitiveness remains absent.

Table 1

Number of SMEs in South Sumatra

\begin{tabular}{lll}
\hline No. & District / City & number of SMEs \\
\hline 1 & Palembang & 28766 \\
2 & Banyu Asin & 3,809 \\
3 & Muba & 11591 \\
4 & OI & 13589 \\
5 & OKI & 9304 \\
6 & OKU & 4059 \\
7 & OKU. East & 3,811 \\
8 & OKU. South & 2246 \\
9 & Prabumulih & 4,861 \\
10 & Muara Enim & 2,877 \\
11 & Lahat & 13860 \\
12 & Pagar Alam & 2,121 \\
13 & Lubuk Linggau & 3,714 \\
14 & Mura & 2902 \\
15 & Empat Lawang & 944 \\
\hline Total & & $\mathbf{1 0 8 \mathbf { 4 }}$ \\
\hline
\end{tabular}

Source: official reports of cooperatives and SMEs, 2017 
Utami and Lantu (2014) suggested that there are six main variables that shape the competitiveness of MSMEs including the availability and conditions of the business environment, the ability of business, policy and infrastructure, research and technology, financial support and partnerships, as well as performance. On the other hand, Mutandwa, Taremwa, and Tubanambazi (2015) stated that the three factors affecting MSMEs are entrepreneurial and marketing ability, working environment, and raw materials and infrastructure. Additionally, Sarwoko and Frisdiantara (2016) proved that MSMEs' growth depends on individual, organisational, and environmental factors. Individual factors consist of family, education, experience, and motivation - organisation factors composed of corporate experience, company size, material, and human resources. At the same time, environmental factors consist of competition, technology, and product diversification. Kimunyi (2015) explained that access to capital, business information services, the characteristics of entrepreneurs, and government policies could affect MSMEs' performance. Furthermore, Fauzi, Antoni, and Suwarni (20020) asserted that financial and digital literacy is one of the important factors that contribute to the MSMEs' sustainability and performance in the long run.

This study predicts MSMEs' performance which have been investigated by Basyith et al. (2014), and Fatimah et al. (2014), especially in internal, marketing, and financial aspects to measure their competitiveness in South Sumatra. To perform this, this investigation included the factors of external influences (capital support, business partners, and infrastructures); technology and research; resources and environmental conditions; and business capabilities (production, entrepreneurship, and service). This study proposes the hypotheses as follows:

$\mathbf{H}_{1}$ : External factors of capital support, business partners, and infrastructure affect the business performance.

$\mathbf{H}_{2}$ : Technology and research affect the business performance.

H3: Production capability, entrepreneurship capability, and service capability affect the business performance.

$\mathbf{H}_{4}$ : Availability of resources and environmental conditions affect the business capabilities.

H5: External factors and technology affect the availability of resources and the environmental conditions.

\section{Research Methodology}

This study employed a questionnaire to collect the data and the variables used are latent variables thus, Structural Equation Modelling is used to analyze the data. Other alternative method that could be employed is Partial Least Square as the sample size is relatively small which is 100 respondents. However, this study employed Structural Equation Modelling to analyze the structural relationship amongst measured and latent variables. This research involved exogenous (resource availability and market conditions), endogenous (MSMEs' performance), path (business capabilities), and moderator (external support and the use of technology) variables. This study analyzed the MSMEs registered on the Department of Cooperatives and SMEs in South Sumatra, with a total of 100. Data were collected through questionnaires consisting of three parts: respondent information, business profiles, and statements made following the objectives. The data analysis utilized structural equation modelling (SEM) processed through AMOS version 20, with the stages of validity, fit, and structural model evaluations. Fig. 1 depicts the conceptual diagram model of this study.

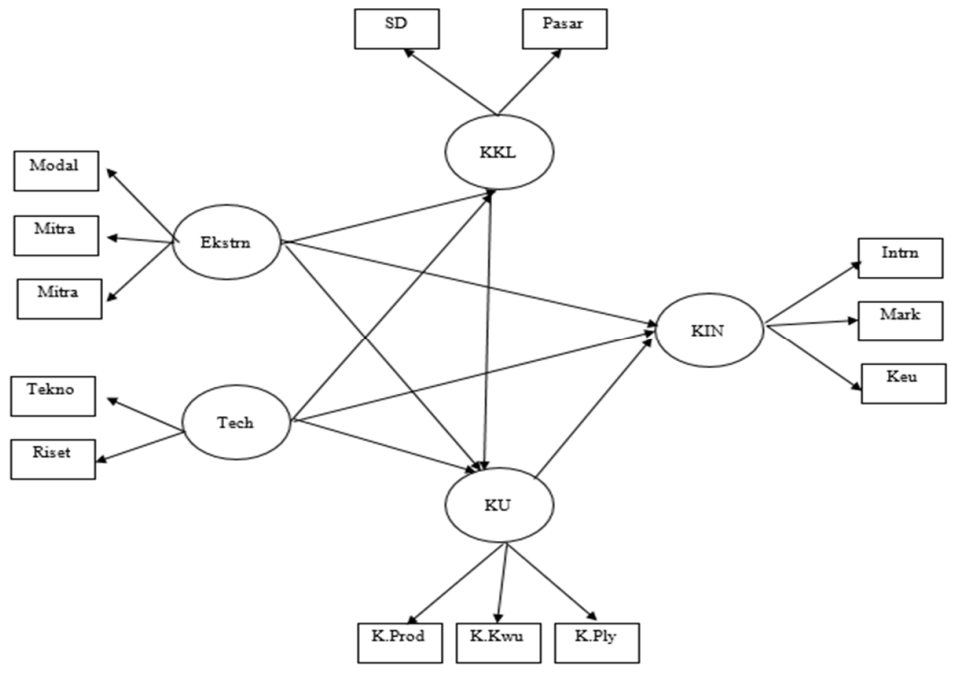

Fig.1. SEM Model

Note: Ekstrn is External; Capital is Capital Support; Partners is Business Partners; Info is Infrastructure; Tech is Technology and Research; KKL is Availability of Resources and Environmental Conditions; SD is Resource; MY is Business Capabilities of Owners and Employees; K.Prod is Production Capability; K.Kwu is Entrepreneurship Capability; K.Ply is Services Capabilities; KIN is Performance; Intern is Internal performance; Mark is Marketing Performance; Keu is Financial Performance. 


\section{Result}

\subsection{Characteristics of Respondents}

This study was conducted in South Sumatra. The province has 15 cities and regencies. From these places, the initial data obtained were 125 . However, due to invalid and incomplete information on the questionnaire responses, the total decreased to 100. The characteristics of the respondents are presented in Table 2. Most of the MSMEs operate in Palembang ( $\mathrm{n}=28$ ), followed by OI and Lahat (each of $n=13)$, and the least is from Empat Lawang $(n=1)$. The majority of MSMEs under study are sole proprietorship $(n=84)$, and the remaining are in partnership $(n=16)$. The divisions of business sectors are food and beverage $(n=47)$; crafts $(n=39)$; agriculture, animal farms, and fisheries $(n=9)$; and finance $(n=5)$. Based on the scale, the MSMEs are dominated by businesses with an annual turnover of Rp. 50,000,000 to Rp. 100,000,000 (n=59), followed by Rp. 100,000,000 - Rp. 300,000,000 (n=21), less than Rp. 50,000,000 (n=16), and Rp. 300,000,000 - Rp. 1,000,000,000 $(\mathrm{n}=4)$.

Table 2

Characteristics of Respondents

\begin{tabular}{llll}
\hline Characteristics & $\mathrm{N}$ & Characteristics & $\mathrm{N}$ \\
\hline Location & & Ownership Type & \\
Palembang & 28 & Sole Proprietorship & 84 \\
Banyu Asin & 3 & Partnership & 16 \\
Muba & 11 & Sector & 47 \\
OI & 13 & Food and Beverage & 39 \\
OKI & 9 & Crafts & 9 \\
OKU & 4 & Agriculture, Animal Farms, and Fisheries & 5 \\
OKU. East & 3 & Finance & \\
OKU. South & 2 & Scale (Turnover/Year) & 16 \\
Prabumulih & 4 & $<50,000,000$ & 59 \\
Muara Enim & 2 & $50,000,000-100,000,000$ & 21 \\
Lahat & 13 & $100,000,000-300,000,000$ & 4 \\
Pagar Alam & 2 & $300,000,000-1,000,000,000$ & - \\
Lubuk Linggau & 3 & $>1,000,000,000$ & \\
Mura & 2 & & \\
Empat Lawang & 1 & & \\
\hline
\end{tabular}

\subsection{Statistical Analysis}

Based on the goodness of fit testings, the results show that four proposed models are fit. The details are given in Table 3.

Table 3

Testing Goodness of Fit Models

\begin{tabular}{lllll}
\hline No. & Test or index & Fit Model Analysis & Acceptable Fit & Decision \\
\hline 1 & Chi-Square Goodness of Fit & $\mathrm{P}>0.00$ & $\mathrm{P}>0.05$ & Unwell \\
2 & GFI & 0.986 & $>0.95$ & Fit \\
3 & RMSEA & 0.176 & $<0.08$ & Unwell \\
4 & CFI & 0.828 & $>0,80$ & Fit \\
5 & $A G F I$ & 0.658 & $>0.90$ & Unwell \\
6 & $I F I$ & 0.831 & $>0.90$ & Unwell \\
7 & $R F I$ & 0.724 & $>0.90$ & Unwell \\
8 & $E C V I$ & 2,690 & 7.15 & Unwell \\
9 & AIC & 360.424 & 7.15 & Unwell \\
10 & $C A I C$ & 493.203 & 2082.32 & Fit \\
11 & $P D F$ & 0.492 & $>0,60$ & Unwell \\
12 & $R M R$ & .449 & $>0.10$ & Fit \\
13 & $N F I$ & .798 & $>0.90$ & Unwell \\
\hline
\end{tabular}

As the goodness of fit model is accepted, the investigation continued to hypothesis testing. The results of it are depicted in Fig. 5. 


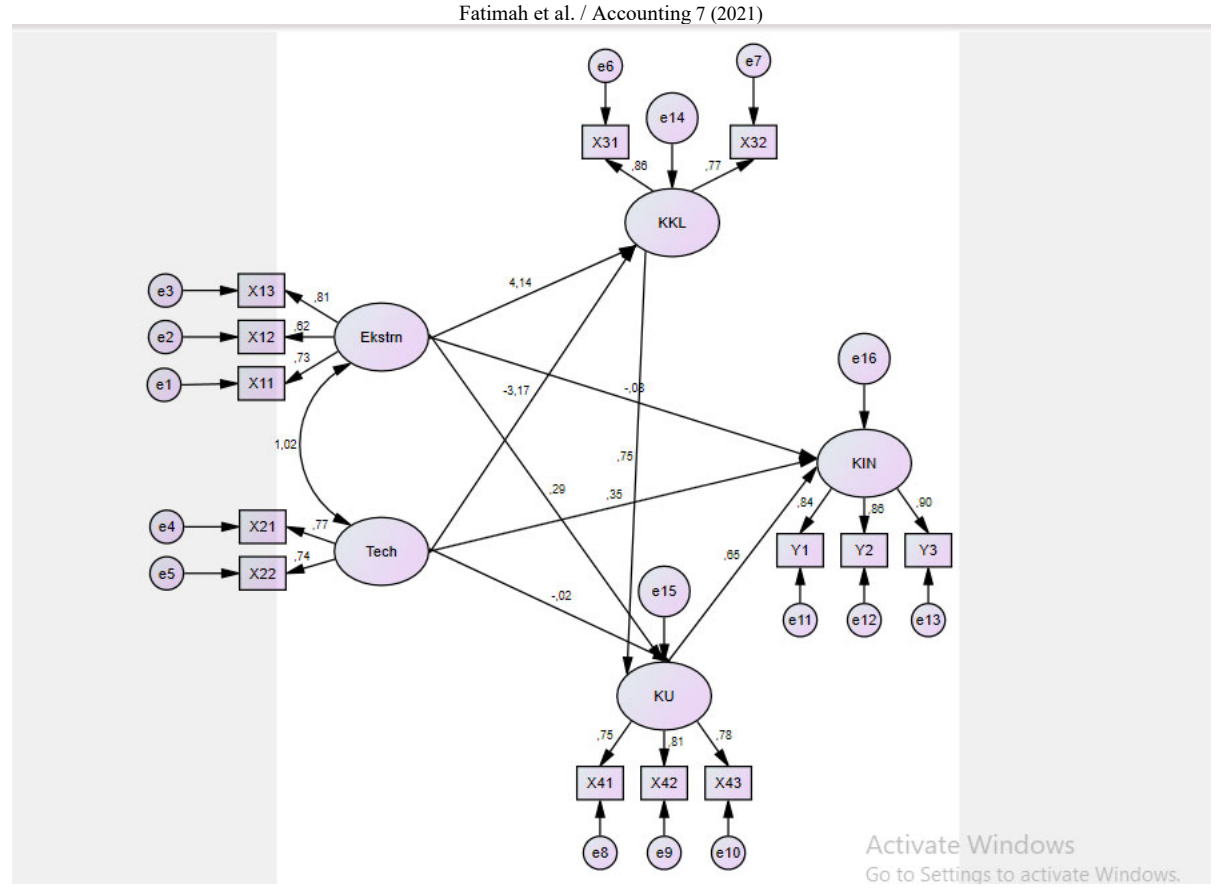

Fig. 5. Model structural analysis results

The results in Fig. 5 are also presented in Table 4. The details are as follows: (1) the external factors have significant and positive effects on resource availability and environmental conditions, and no significant effect on the capability of business owners and employees; (2) technology and research has positive and significant impacts on the availability of resources and environmental conditions and the capability of business owners and employees; (3) the availability of resources and environmental conditions has a significant and positive effect on the capability of business owners and employees; (4) the availability of resources and environmental conditions and the capability of business owners and employees have positive and significant impacts on the performance of MSMEs; and (5) the external factors have no significant effect on the capability of business owners and employees and the performance of MSMEs.

Table 4

Hypothesis Testing

\begin{tabular}{|c|c|c|c|c|c|c|c|}
\hline & & & estimate & SE & $\mathrm{CR}$ & $\mathrm{P}$ & Conclusion \\
\hline KKL & $\leftarrow$ & Ekstrn &, 648 &, 207 & 3.131 & $* * *$ & Accepted \\
\hline KKL & $\leftarrow$ & Tech &, 356 &, 053 & 6.717 & $* * *$ & Accepted \\
\hline MY & $\leftarrow$ & Ekstrn &, 332 &, 321 & 1,037 &, 300 & Rejected \\
\hline MY & $\leftarrow$ & Tech &, 342 &, 112 & 3.054 & .002 & Accepted \\
\hline MY & $\leftarrow$ & KKL &, 630 & , 206 & 3,057 & .002 & Accepted \\
\hline KIN & $\leftarrow$ & Ekstrn &, 159 &, 516 &, 307 &, 758 & Rejected \\
\hline KIN & $\leftarrow$ & Tech &, 583 &, 171 & 3,410 & $* * *$ & Accepted \\
\hline KIN & $\leftarrow$ & MY & 1,070 &, 554 & 1.931 & .048 & Accepted \\
\hline X11 & $\leftarrow$ & Ekstra & 1,000 & & & & Accepted \\
\hline $\mathrm{X} 12$ & $\leftarrow$ & Ekstrn & 1,064 &, 154 & 6,918 & $* * *$ & Accepted \\
\hline X13 & $\leftarrow$ & Ekstra & 1.839 &, 201 & 9.158 & $* * *$ & Accepted \\
\hline $\mathrm{X} 22$ & $\leftarrow$ & Tech &, 990 &, 101 & 9.751 & $* * *$ & Accepted \\
\hline X21 & $\leftarrow$ & Tech & 1,000 & & & & Accepted \\
\hline X31 & $\leftarrow$ & KKL & 1,000 & & & & Accepted \\
\hline X32 & $\leftarrow$ & KKL &, 948 &, 087 & 10.910 & $* * *$ & Accepted \\
\hline X43 & $\leftarrow$ & MY & 1,000 & & & & Accepted \\
\hline $\mathrm{x} 42$ & $\leftarrow$ & MY & 1,357 &, 129 & 10.555 & $* * *$ & Accepted \\
\hline X41 & $\leftarrow$ & MY & 1,315 &, 138 & 9.534 & $* * *$ & Accepted \\
\hline Y3 & $\leftarrow$ & KIN & 1,000 & & & & Accepted \\
\hline $\mathrm{Y} 2$ & $\leftarrow$ & KIN & 1,018 &, 073 & 13.872 & $* * *$ & Accepted \\
\hline Y1 & $\leftarrow$ & KIN & 1,106 &, 082 & 13.486 & $* * *$ & Accepted \\
\hline
\end{tabular}

The results above can also be described in the following equation models: 
First Substructural

$$
\begin{aligned}
& M P A=b 1+b 2 \text { Ekstrn Tech }+e 1 \\
& M P A=0,648 \text { Ekstrn 0,356Tech }+e 1
\end{aligned}
$$

Second Substructural

KKL KU $=$ b3 + b4 + b5 Ekstrn Tech + e1

$K U=0,630 K K L+0,332 E k s t r n+0,342 T e c h+e 1$

Third Substructural

$$
\begin{aligned}
& K I N=b 6 K U+b 7 E k s t r n+b 8 T e c h+e 1 \\
& K I N=1,070 K U+0,159 E k s t r n+0,583 T e c h+e 1
\end{aligned}
$$

Table 5

Direct, indirect, and total effects

\begin{tabular}{llll}
\hline effect & Direct Effect & indirect Effect & total Effect \\
\hline external $\rightarrow$ KKL & 0.648 & - & 0.648 \\
Tech $\rightarrow$ KKL & .356 & - & .356 \\
external $\rightarrow$ MY & 0.332 & 0.408 & .740 \\
Tech $\rightarrow$ MY & 0.342 & .224 & .566 \\
KKL $\rightarrow$ MY & .630 & - & .630 \\
MY $\rightarrow$ KIN & 1,070 & & 1,070 \\
external $\rightarrow$ KIN & .159 & .437 & .596 \\
Tech $\rightarrow$ KIN & 0.583 & .240 & 0.823 \\
\hline
\end{tabular}

\section{Discussion}

The findings evidenced that the external factors of capital support, business partners, and infrastructure affecting the availability of resources and environmental conditions. Further, these external factors directly have no significant effects, but indirectly have significant effects on the capability of business owners and employees and the performance of MSMEs. The results are consistent with Kimunyi (2015), where he found that the capital support, business information services, the characteristics of entrepreneurs, and government policies significantly affect the performance of MSMEs. Additionally, this study also is in line with Mutandwa, Taremwa, and Tubanambazi (2015) where he showed that entrepreneurial and marketing, working environment, and raw materials and infrastructure can affect MSMEs' competitiveness.

MSMEs heavily rely on the economic system and governmental support, especially in South Sumatra. The findings in this study provide insights to the Department of Cooperatives and SMEs in the region. To create more competitive MSMEs, the government should enhance capital supports, business partnership, and infrastructures for the respective MSMEs. Government, as policymakers, must provide real support in the provision of MSME development fund. Although this variable is directly insignificant, funding is highly substantial for innovation (Bates, Manuel, and Oppenheim, 2007). Also, early entrepreneurs typically encounter hindrances in financing their businesses (Sultan and Sultan, 2020). The provision of funding is likely to improve workforce, machines, materials, and raw materials. Also, the help of funds can improve business owners and employees' capability through participation in education. Education in this context includes the formal and informal training (Lock and Smith, 2016). Because entrepreneurship capability relates to educational level and working experience (Minniti and Naudé, 2010), it is reasonable that education eventually affects MSMEs' success (Gray and FinleyHervey, 2005). Business partnership is also paramount in developing the MSMEs. Such partnership also refers to social networks a business possesses. The business networks ease the MSMEs' growth, provide better access to resources, and inflate opportunities (Zimmer, 1986). The networks also can transfer business knowledge from one partner to another (Mekonnen and Cestino, 2017; Tortoriello, Reagans, and McEvily, 2012). It then can provide a better business practice which eventually intensifies competitive advantage. Finally, the government should also provide exceptional infrastructures to facilitate distribution to consumers and streamline costs

In contrast to the external factors, the use of technology and research directly affects the performance of MSMEs and indirectly through the availability of resources and environmental conditions and business owners and employees' capability. The results are consistent with Lantu, Triady, Utami, and Ghazali (2016), which proved that research and technology are one of the primary aspects amplifying MSMEs' competitiveness. This information exhibits that MSMEs should implement research and technology in their business practices. This is because the application of technology and research will promote innovation. According to Anderson, Potočnik, and Zhou (2014) and Baregheh, Rowley, and Sambrook (2009), innovation is a set of processes to create a new way of doing things performed by a business entity with the end goals to differentiate itself from the market and attain success. Bates and Robb (2014) discovered that innovative MSME owners might operate their businesses feasibly. 


\section{Conclusion}

In conclusion, the external factors of capital support, business partners, and infrastructure directly have no effects but indirectly affect the performance of MSMEs in South Sumatra. In addition, the availability of resources and environmental conditions; and the capability of business owners and employees indirectly affect the performance of MSMEs in South Sumatra. Lastly, the use of technology and research affects the performance of MSMEs in South Sumatra directly and indirectly through the availability of resources and environmental conditions and business owners and employees' capability. The insights from this study are beneficial for governments and policymakers. They should provide and enhance the MSMEs ecosystem in South Sumatra. Specifically, there should be provision of support in the forms of capital, business partners, infrastructure, technology, and research. Despite the benefits, this study also carries several limitations. The samples are small and concentrated in one region. Future study should include more samples from different regions.

Authors' individual contribution: Conceptualization - F.; Methodology - F., and FF.; Investigation - F., A.D., and FF.; Resources - F.; Writing - F., A.D., and FF.; Supervision - FF.

Declaration of conflicting interests: The Authors declare that there is no conflict of interest.

\section{References}

Alyas, M. R. (2017). Strategi Pengembangan Usaha Mikro, Kecil dan Menengah Dalam Penguatan Ekonomi Kerakyatan (Studi Kasus Pada Usaha Roti Maros di Kabupaten Maros).

Anderson, N., Potočnik, K., \& Zhou, J. (2014). Innovation and creativity in organizations: A state-of-the-science review, prospective commentary, and guiding framework. Journal of Management, 40(5), 1297-1333.

Aribawa, D. (2016). Pengaruh literasi keuangan terhadap kinerja dan keberlangsungan UMKM di Jawa Tengah. Jurnal Siasat Bisnis, 20(1), 1-13.

Baregheh, A., Rowley, J., \& Sambrook, S. (2009). Towards a multidisciplinary definition of innovation. Management decision, 47(8), 1323-1339.

Basyith, A., Idris, M., \& Fauzi, F. (2014). The gender effect on small business enterprises' firm performance: Evidence from Indonesia. Indian Journal of Economics and Business, 12(1), 21-39. Retrieved from https://serialsjournals.com/abstract/66890_2-abdul_basyith.pdf

Bates, M., Manuel, S., \& Oppenheim, C. (2007). Models of early adoption of ICT innovations in higher education.

Bates, T., \& Robb, A. (2014). Small-business viability in America's urban minority communities. Urban Studies, 51(13), 2844-2862.

Fatimah, Fauzi, F., \& Basyith, A. (2014). Small business financing: Determinants and obstacles in the context of Indonesia. International Research Journal of Finance and Economics, 95-116.

Fauzi, F., Antoni, D., \& Suwarni, E. (2020). Women entrepreneurship in the developing country: The effects of financial and digital literacy on SMEs' growth. Journal of Governance and Regulation, 9(4), 106-115.

Gray, K. R., \& Finley-Hervey, J. (2005). Women and entrepreneurship in Morocco: Debunking stereotypes and discerning strategies. The International Entrepreneurship and Management Journal, 1(2), 203-217.

Hanum, A. N., \& Sinarasri, A. (2018). Analisis faktor-faktor yang mempengaruhi adopsi e commerce dan pengaruhnya terhadap kinerja umkm (studi kasus umkm di wilayah kota semarang). MAKSIMUM: Media Akuntansi Universitas Muhammadiyah Semarang, 8(1), 1-15.

Kimunyi, I. M. (2015). Factors influencing performance of small and medium enterprise tea firms in Mombasa County, Kenya (Doctoral dissertation, University of Nairobi).

Lock, R., \& Smith, H. L. (2016). The impact of female entrepreneurship on economic growth in Kenya. International Journal of Gender and Entrepreneurship, 8(1), 91-96.

Mekonnen, H. D., \& Cestino, J. (2017). The impact of the institutional context on women's entrepreneurship in Ethiopia: breaking the cycle of poverty?. In Contextualizing entrepreneurship in emerging economies and developing countries. Edward Elgar Publishing.

Minniti, M., \& Naudé, W. (2010). What do we know about the patterns and determinants of female entrepreneurship across countries?.

Mutandwa, E., Taremwa, N. K., \& Tubanambazi, T. (2015). Determinants of business performance of small and medium size enterprises in Rwanda. Journal of Developmental Entrepreneurship, 20(01), 1550001.

Nicolescu, O. (2009). Main features of SMEs organisation system. Revista de Management Comparat Internațional, 10(3), 405-413.

Rahayu, A. Y. (2017). Pengaruh literasi keuangan terhadap kinerja dan keberlanjutan UMKM di kota Surabaya. Jurnal Ilmu Manajemen (JIM), 5(3).

Sarwoko, E., \& Frisdiantara, C. (2016). Growth determinants of small medium enterprises (SMEs). Universal Journal of Management, 4(1), 36-41.

Sultan, S., \& Sultan, W. I. (2020). Women MSMEs in times of crisis: challenges and opportunities. Journal of Small Business and Enterprise Development, 27(2). 
Tortoriello, M., Reagans, R., \& McEvily, B. (2012). Bridging the knowledge gap: The influence of strong ties, network cohesion, and network range on the transfer of knowledge between organizational units. Organization Science, 23(4), 1024-1039.

Utami, R. M., \& Lantu, D. C. (2014). Development competitiveness model for small-medium enterprises among the creative industry in Bandung. Procedia-Social and Behavioral Sciences, 115, 305-323.

Zimmer, C. (1986). Entrepreneurship through social networks. The art and science of entrepreneurship. Ballinger, Cambridge, $M A, 3,23$.

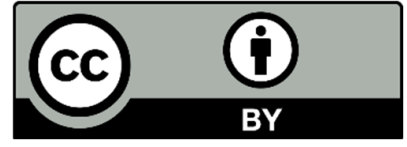

(C) 2021 by the authors; licensee Growing Science, Canada. This is an open access article distributed under the terms and conditions of the Creative Commons Attribution (CC-BY) license (http://creativecommons.org/licenses/by/4.0/). 